Research Article

\title{
Meningkatkan Kemampuan Siswa dalam Menjumlahkan dan Mengurangkan Suatu Bilangan dengan Bantuan Media Batu Kerikil di Kelas I SDN 177/I Tapah Sari
}

\section{Rusmini}

SDN 177/I Tapah Sari, Batanghari, Jambi, Indonesia

Article Information

Reviewed : Nov 29, 2019

Revised : Dec 23, 2019

Available Online : Dec 31, 2019

\section{Keyword}

Penjumlahan,

Pengurangan, MTK,

Sekolah Dasar

\section{Corespondence}

e-mail :

rusmini.sdn177@yahoo.com

\section{ABSTRACT}

The purpose of this study is to improve students' ability to add and subtract a number with the help of gravel media in class I students at SDN 177 / I Tapah Sari, Batanghari Regency, Jambi. This research was conducted in grade 1 students with a total of 13 male students and 11 female students. Before the improvement was held there were only 14 students who had not been able to reach the KKM 65, in the first cycle students who achieved KKM became 20 students, and in the second cycle increased to 24 students or all students had reached the KKM. From this study it can be seen that there is an increase in students' abilities as follows: On average before the holding of the improvement, $58.33 \%$ of the first cycle increased to $83.33 \%$ and in the second cycle increased again to $100 \%$. This proves that the use of gravel media assistance can improve students' ability to add and subtract numbers.

\section{DOI : https://doi.org/10.22437/gentala.v4i2.8468}

\section{PENDAHULUAN}

Pendidikan merupakan tanggung jawab keluarga sekolah dan lingkungan. Keberhasilan pendidikan tiga komponen tersebut sangat menentukan. Disamping tiga komponen tersebut, metode atau strategi pembelajaran, alat-alat pembelajaran juga mutlak diperlukan. Pendidikan merupakan usaha manusia untuk menyiapkan diri dalam peranannya dimasa akan datang dan pendidikan dilakukan tanpa batasan usia, ruang dan waktu yang tidak dimulai atau diakhiri di sekolah, tetapi diawali dalam keluarga dilanjutkan lingkungan sekolah dan diperkaya oleh lingkungan masyarakat, yang hasilnya digunakan untuk membangun kehidupan pribadi agama, masyarakat, keluarga, dan negara.

Guna mencapai tujuan pendidikan, guru sebagai pendidik dituntut untuk memiliki kemampuan yang baik karena antar siswa sebagai peserta didik dan guru sebagai pendidik merupakan suatu interaksi. Apabila dikaitkan dengan penjumlahan dan pengurangan maka mengoprasionalkan penjumlajan dan pengurangan maka melaksanakan suatu kegiatan 


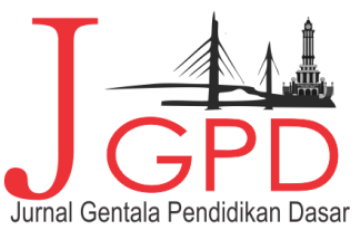

JURNAL geNTALA PENDIDIKAN DASAR Vol. 4 No. 2 December 20I9 Page 264-271

P-ISSN : 2614-7092, E-ISSN : 2621-966II

Available Dnline at Web : http://online-journal.unja.ac.id/index.php/gentala email : penyunting.jurnal.q-pgsd国unja.ac.id

menjumlah dan mengurang suatu bilangan. Mengoprasionalkan suatu kegiatan tidaklah mudah, guru sebagai pendidik harus mampu mmemilih strategi, metode ataupun Media yang tepat untuk melaksanakannya.

Menurut Piaget, anak usia 7-12 tahun (Usia Sekolah Dasar) masih dalam tahap operasional konkret. Dari usia perkembangan kognitif, siswa sekolah dasar masih terikat dengan benda konkret yang dapat dilihat secara langsung. Dalam pembelajaran matematika siswa memerlukan alat bantu yang dapat memperjelas apa yang telah disampaikan oleh guru sehingga pembelajaran dapat tercapai. Salah satu benda konkret yang dapat digunakan adalah media berupa batu kerikil. Dimana batu kerikil juga mudah didapatkan di sekitar siswa.

Menurut Pramudjono (Sundayana, 2015:7) "Alat peraga adalah benda konkret yang dibuat, dihimpun atau disusun secara sengaja digunakan untuk mem bantu menanamkan atau mengembangkan konsep matematika. Alat peraga dapat diartikan suatu alat atau bahan yang digunakan oleh pendidik untuk membantu peserta didik dalam meningkatkan keterampilan dan pengetahuan".

Berdasarkan hasil belajar yang diperloh di kelas I, yaitu pada saat pembelajaran penjumlahan dan pengurangan guru telah memanfaatkan media yang ada seperti papan tulis, spidol, dan buku paket. Namun, pada siswa kelas 1 dengan jumlah siswa laki-laki sebanyak 13 orang dan siswa perempuan sebanyak 11 orang. Hanya terdapat 14 siswa yang dapat mencapai nilai KKM 65. Artinya sebagian besar siswa masih kesulitan dalam memahami operasi penjumlahan dan pengurangan.

Melihat kondisi ini tentu saja perlu segera dicari solusinya. Untuk menciptakan pembelajaran yang efektif, efisien dan menyenangkan maka guru harus menggunakan media dalam proses pembelajaran. Selain itu, guru dapat menumbuhkan ketertarikan belajar siswa, salah satunya dengan menggunakan media batu krikil sebagi media konkret yang dapat membantu siswa dalam menjumlahkan dan mengurangkan.

Berdasarkan uraian yang telah dijelaskan, maka saya tertarik mengangkat judul penelitian : Meningkatkan Kemampuan Siswa dalam Menjumlahkan dan Mengurangkan Suatu Bilangan dengan Bantuan Media Batu Kerikil di Kelas I SDN 177/I Tapah Sari. 


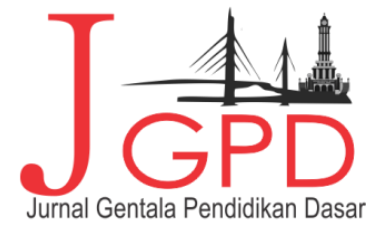

JURNAL geNTALA PENDIDIKAN DASAR Vol.4 No. 2 December 2019 Page 264-271

P-ISSN : 2614-7092, E-ISSN : 2621-961|

Available Dnline at Web : http://anline-journal.unja.ac.id/index.php/gentala

email : penyunting.jurnal.g-pgsd国unja.ac.id

\section{METODE PENELITIAN}

\section{Jenis Penelitian}

Penelitian ini merupakan jenis Penelitian Tindakan Kelas (PTK). Penelitian ini dimaksudkan untuk memperbaiki proses pembelajaran, sehingga dapat meningkatkan kemampuan siswa dalam menjumlahkan dan mengurangkan suatu bilangan dengan bantuan media batu kerikil.

\section{Waktu Penelitian}

Penelitian tindakan kelas ini dilaksanakan di SDN 177/I Tapah Sari, Kabupaten Batanghari, Jambi pada semester ganjil 2019/2020.

\section{Subjek Penelitian}

Subjek penelitian pada penelitian ini adalah peserta didik kelas I SDN 177/I Tapah Sari, Kabupaten Batangahri, Jambi yang be rjumlah 24 peserta didik yang terdiri dari 13 peserta didik laki-laki dan 11 peserta didik perempuan.

\section{Prosedur Penelitian}

Dalam penelitian ini, peneliti menggunakan alur penelitian tindakan kelas Kemis dan Taggart, yaitu berbentuk spiral dan siklus yang satu ke siklus berikutnya. Masing-masing siklus terdiri dari: perencanaan, pelaksanaan, observasi dan refleksi. Langkah pada siklus berikutnya adalah perencanaan yang sudah direvisi, tindakan, pengamatan, dan refleksi.

\section{Teknik Pengumpulan Data}

Teknik pengumpulan data yang di gunakan pada penelitian ini adalah observasi dan tes. Observasi dalam penelitian ini merupakan teknik pengumpulan data melalui pengamatan dan pencatatan terhadap proses pembelajaran menggunakan media batu kerikil.

Tes digunakan untuk melihat kemampuan siswa dalam menghitung dan mengurangkan suatu bilangan.

\section{Instrumen Penelitian}

Lembar Observasi Keterlaksanaan RPP, dalam penelitian ini digunakan untuk memperoleh informasi mengenai terlaksananya kegiatan pembelajaran oleh guru. Instrumen selanjutnya Soal Tes Tertulis. 


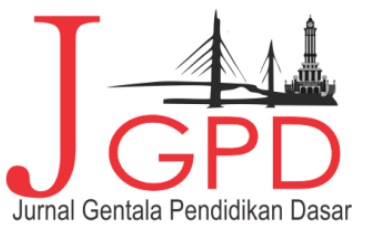

JURNAL geNTALA PENDIDIKAN DASAR Vol.4 No. 2 December 2019 Page 264-271

P-ISSN : 2614-7092, E-ISSN : 2621-961|

Available Dnline at Web : http://anline-journal.unja.ac.id/index.php/gentala email : penyunting.jurnal.g-pgsd国unja.ac.id

\section{Teknik Analisis Data}

Analisis data dilakukan untuk menguji hipotesis dari penelitian. Analisis penelitian menggunakan analisis kualitatif dan analisis kuantitatif. Analisis kualitatif yaitu menggambarkan data dengan kalimat untuk memperoleh keterangan yang jelas dan terperinci. Teknis analisis data ini diperoleh dengan cara merefleksikan hasil observasi.

Analisis tes kemampuan berhitung siswa menggunakan persentase menggunakan skala gutman dan rumus menurut Aries dan Haryono (2012: 95) sebagai berikut:

$$
\frac{\sum \text { skor yang didapat }}{\sum \text { skor maksimal }} \times 100
$$

\section{Kriteria Keberhasilan}

Kriteria keberhasilan dalam penelitian ini yaitu adanya peningkatan bertanya siswa ditandai dengan rata-rata nila-nilai siswa mencapai KKM yaitu 65 dan presentase banyaknya siswa yang tuntas minimum $75 \%$, maka penelitian dikatakan berhasil.

\section{HASIL PENELITIAN DAN PEMBAHASAN}

Adapun hasil penelitian ini akan dijasikan dalam tabel dibawah ini :

Tabel 1. Hasil Tes Kemampuan Menjumlahkan dan Mengurangkan Siswa sebelum Tindakan

\begin{tabular}{|l|l|l|l|}
\hline No & Nama Siswa & Nilai & Keterangan \\
\hline 1 & Ahmad Arif Pratama & 65 & Tuntas \\
\hline 2 & Akbar M Nur & 70 & Tuntas \\
\hline 3 & Al Chaisar Dewantara & 60 & Tidak Tuntas \\
\hline 4 & Alfian Nur Hidayat & 50 & Tidak Tuntas \\
\hline 5 & Arga Setiawan & 65 & Tuntas \\
\hline 6 & Bayu Rizky Adha & 60 & Tidak Tuntas \\
\hline 7 & Carissa Muharno Putri & 70 & Tuntas \\
\hline 8 & Firman gea & 75 & Tuntas \\
\hline 9 & Grace Natasya Sitohang & 60 & Tidak Tuntas \\
\hline 10 & Hafiz Arkananta & 50 & Tidak Tuntas \\
\hline 11 & Julfa Mawarda & 50 & Tidak Tuntas \\
\hline 12 & Kris Anugrah Laowa & 60 & Tidak Tuntas \\
\hline 13 & Muhammad Ardito Jesan Prayoga & 65 & Tuntas \\
\hline 14 & Naura Allesia Putri & 65 & Tuntas \\
\hline 15 & Nur hafizd ahmad & 70 & Tuntas \\
\hline 16 & Nuril Aulia & 60 & Tidak Tuntas \\
\hline 17 & Sehati gulo & 50 & Tidak Tuntas \\
\hline 18 & Siti Nur Azizah & 50 & Tidak Tuntas \\
\hline 19 & Siti Nur Haliman & 60 & Tidak Tuntas \\
\hline
\end{tabular}


Available Dnline at Web : http://online-journal.unja.ac.id/index.php/gentala email : penyunting.jurnal.g-pgsd国unja.ac.id

\begin{tabular}{|l|l|l|l|}
\hline 20 & Sudirman gulo & 65 & Tuntas \\
\hline 21 & Surya husein ramadhan & 55 & Tidak Tuntas \\
\hline 22 & Wilda Khanifa rahim & 50 & Tidak Tuntas \\
\hline 23 & Wita Maharani & 60 & Tidak Tuntas \\
\hline 24 & Khaira Amanda & 65 & Tuntas \\
\hline \multicolumn{2}{|l|}{ Jumlah Siswa Tuntas } & & 10 org / 41,66\% \\
\hline Jumlah Siswa Tidak Tuntas & 14 org / 58,33\% \\
\hline
\end{tabular}

Tabel 2. Hasil Tes Kemampuan Menjumlahkan dan Mengurangkan Siswa Siklus I

\begin{tabular}{|l|l|l|l|}
\hline No & Nama Siswa & Nilai & Keterangan \\
\hline 1 & Ahmad Arif Pratama & 80 & Tuntas \\
\hline 2 & Akbar M Nur & 80 & Tuntas \\
\hline 3 & Al Chaisar Dewantara & 75 & Tuntas \\
\hline 4 & Alfian Nur Hidayat & 60 & Tidak Tuntas \\
\hline 5 & Arga Setiawan & 80 & Tuntas \\
\hline 6 & Bayu Rizky Adha & 80 & Tuntas \\
\hline 7 & Carissa Muharno Putri & 85 & Tuntas \\
\hline 8 & Firman gea & 90 & Tuntas \\
\hline 9 & Grace Natasya Sitohang & 80 & Tuntas \\
\hline 10 & Hafiz Arkananta & 80 & Tuntas \\
\hline 11 & Julfa Mawarda & 60 & Tidak Tuntas \\
\hline 12 & Kris Anugrah Laowa & 80 & Tuntas \\
\hline 13 & Muhammad Ardito Jesan Prayoga & 85 & Tuntas \\
\hline 14 & Naura Allesia Putri & 85 & Tuntas \\
\hline 15 & Nur hafizd ahmad & 90 & Tuntas \\
\hline 16 & Nuril Aulia & 85 & Tuntas \\
\hline 17 & Sehati gulo & 75 & Tuntas \\
\hline 18 & Siti Nur Azizah & 80 & Tuntas \\
\hline 19 & Siti Nur Haliman & 80 & Tuntas \\
\hline 20 & Sudirman gulo & 65 & Tuntas \\
\hline 21 & Surya husein ramadhan & 60 & Tidak Tuntas \\
\hline 22 & Wilda Khanifa rahim & 60 & Tidak Tuntas \\
\hline 23 & Wita Maharani & 85 & Tuntas \\
\hline 24 & Khaira Amanda & 80 & Tuntas \\
\hline Jumlah Siswa Tuntas & & 20 org / 83,33\% \\
\hline Jumlah Siswa Tidak Tuntas & & 4 org / $16,66 \%$ \\
\hline & & \\
\hline
\end{tabular}

\section{Refleksi Siklus I}

Setelah dilakukan kegiatan siklus I, dirasa ada beberapa kendala yang ditemukan yaitu seperti : sulitnya mengontrol siswa karena pembelajaran dilakukan menggunakan demonstrasi., sehingga cara ini perlu ditambah menggunakan strategi kelompok agar lebih 


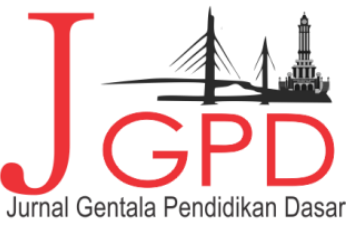

JURNAL GeNTALA PENDIDIKAN DASAR Vol.4 No. 2 December 20I9 Page 264-271 P-ISSN : 2614-7092, E-ISSN : 2621-961I

Available Online at Web : http://online-journal.unja.ac.id/index.php/gentala email : penyunting.jurnal.q-pgsd国unja.ac.id

dapat terkontrol. Serta siswa yang telah bisa menguasai materi dapat membantu mengajrkan pada siswa yang lain dalam kelompok.

Tabel 3. Hasil Tes Kemampuan Menjumlahkan dan Mengurangkan Siswa Siklus II

\begin{tabular}{|l|l|l|l|}
\hline No & Nama Siswa & Nilai & Keterangan \\
\hline 1 & Ahmad Arif Pratama & 100 & Tuntas \\
\hline 2 & Akbar M Nur & 100 & Tuntas \\
\hline 3 & Al Chaisar Dewantara & 95 & Tuntas \\
\hline 4 & Alfian Nur Hidayat & 95 & Tuntas \\
\hline 5 & Arga Setiawan & 100 & Tuntas \\
\hline 6 & Bayu Rizky Adha & 100 & Tuntas \\
\hline 7 & Carissa Muharno Putri & 100 & Tuntas \\
\hline 8 & Firman gea & 100 & Tuntas \\
\hline 9 & Grace Natasya Sitohang & 95 & Tuntas \\
\hline 10 & Hafiz Arkananta & 95 & Tuntas \\
\hline 11 & Julfa Mawarda & 90 & Tuntas \\
\hline 12 & Kris Anugrah Laowa & 100 & Tuntas \\
\hline 13 & Muhammad Ardito Jesan Prayoga & 95 & Tuntas \\
\hline 14 & Naura Allesia Putri & 100 & Tuntas \\
\hline 15 & Nur hafizd ahmad & 100 & Tuntas \\
\hline 16 & Nuril Aulia & 100 & Tuntas \\
\hline 17 & Sehati gulo & 100 & Tuntas \\
\hline 18 & Siti Nur Azizah & 100 & Tuntas \\
\hline 19 & Siti Nur Haliman & 100 & Tuntas \\
\hline 20 & Sudirman gulo & 95 & Tuntas \\
\hline 21 & Surya husein ramadhan & 90 & Tuntas \\
\hline 22 & Wilda Khanifa Rahim & 90 & Tuntas \\
\hline 23 & Wita Maharani & 100 & Tuntas \\
\hline 24 & Khaira Amanda & 100 & Tuntas \\
\hline Jumlah Siswa Tuntas & & 24 org / 100\% \\
\hline Jumlah Siswa Tidak Tuntas & & 0 org / 0\% \\
\hline & & \\
\hline
\end{tabular}

\section{Refleksi Siklus II}

Berdasarkan perencanaan yang telah disusun ulang pada siklus I, didapatkan bahwa pembelajaran lebih menarik, siswa tergabung di dalam kelompoknya masing-masing, dan lebih memudahkan untuk mengontrol setipa individu dalam kelompok. Setiap siswa pun telah mencapai KKM yang ditentukan. Sedangkan keterlaksanaan RPP yang dilakukan guru telah terlaksana $100 \%$ setiap langkahmya. 


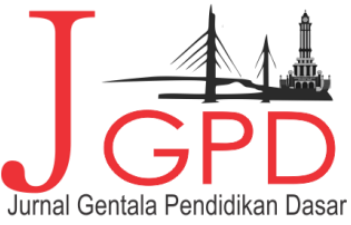

Pembahasan

Sesuai dengan tujuan dari penelitian ini adalah Meningkatkan kemampuan siswa dalam menjumlahkan dan mengurangkan suatu bilangan dengan bantuan media batu kerikil pada siswa kelas I SDN 177/I Tapah Sari Kabupaten Batanghari, Jambi. Menurut Carr dan Kemmis seperti yang dikutip oleh Siswojo Hardjodipuro, dikatakan bahwa yang dimaksud dengan istilah PTK adalah suatu bentuk refleksi diri yang dilakukan oleh para partisipan (guru, siswa atau kepala sekolah) dalam situasi-situasi sosial (termasuk pendidikan) untuk memperbaiki rasionalitas dan kebenaran (a) praktik-praktik sosial atau pendidikan yang dilakukan dilakukan sendiri, (b) pengertian mengenai praktik-praktik ini, dan (c) situasisituasi ( dan lembaga-lembaga ) tempat praktik-praktik tersebut dilaksanakan (Harjodipuro, 1997).

Penelitian ini dilakukan pada siswa kelas 1 dengan jumlah siswa laki-laki sebanyak 13 orang dan siswa perempuan sebanyak 11 orang. Sebelum diadakan perbaikan hanya terdapat 14 siswa yang belum dapat mencapai nilai KKM 65, pada siklus I siswa yang mencapai KKM menjadi 20 siswa, dan pada siklus II meningkat menjadi 24 siswa atau seluruh siswa telah bisa mencapai KKM. Melihat hasil peningkatan setiap siklus, membuktikan bahwa penggunaan bantuan media batu kerikil dapat meningkatkan kemampuan siswa dalam menjumlahkan dan mengurangkan suatu bilangan. Artinya media pembelajaran memang sangat diperlukan dalam membantu siswa belajar. Sesuai dengan teorinya yaitu Rayanda Asyar (2012:8) mengemukakan bahwa " media pembelajaran dapat dipahami sebagai segala sesuatu yang dapat menyampaikan atau menyalurkan pesan dari sumber secara terencana, sehingga terjadi lingkungan belajar yang kondusif dimana penerimanya dapat melakukan proses belajar secara efisien dan efektif.

\section{KESIMPULAN DAN IMPLIKASI}

\section{Kesimpulan}

Dari penelitian ini dapat dilihat adanya peningkatan kemampuan siswa sebagai berikut: Rata-rata sebelum diadakannya perbaikan 58,33\% siklus I meningkat menjadi 83,33\% dan pada siklus II meningkat lagi menjadi 100\%. Ini membuktikan bahwa penggunaan bantuan media batu kerikil dapat meningkatkan kemampuan siswa dalam menjumlahkan dan mengurangkan suatu bilangan. 


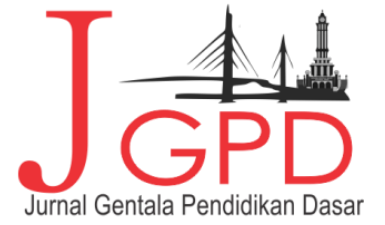

\section{Implikasi}

Implikasi dari penelitian ini dapat mengetahui kemampuan siswa dalam pembelajaran matematika materi penjumlahan dan pengurangan suatu bilangan dengan bantuan media batu kerikil. hasil penelitian juga ditemukan bahwa terdapat perbedaan daya tarik siswa dalam belajar sebelum dan setelah menggunakan media batu kerikil yang digunakan saat proses pembelajaran.

\section{DAFTAR PUSTAKA}

Asyar, Rayandra. 2011. Kreatif Mengembangkan Media Pembelajaran. Jakarta: Gaung Persada (GP) Press.

Chan, F., Sofwan, M., \& Putri, N. D. (2018). Meningkatkan Keaktifan Belajar Siswa Menggunakan Media Gambar Di Sekolah Dasar. Jurnal Gentala Pendidikan Dasar, 3(1), 57-72.

Kurniawan, A. R., Noviyanti, S., \& Arsil, A. (2019). Optimasi Model Problem Based Learning Berbantuan Multimedia untuk Meningkatkan Keterampilan Kerja Tim di Sekolah Dasar. ELSE (Elementary School Education Journal): Jurnal Pendidikan dan Pembelajaran Sekolah Dasar,3(2), 7-16.Hamalik, Oemar. 2008. Kurikulum dan Pembelajaran. Jakarta: Bumi Aksara.

Majid, Abdul. 2014. Pembelajaran Tematik Terpadu. Bandung: PT Remaja Rosdakarya.

Pitajeng. 2006. Pembelajaran Matematika Yang Menyenangkan. Jakarta: Departemen Pendidikan Nasional Direktorat Jenral Pendidikan Tinggi.

Runtukahu dan Kanduo. 2016. Pembelajaran Matematika Dasar Bagi Anak Berkesulitan Belajar. Yogyakarta: Ar-ruzz Media.

Rusman. 2015. Pembelajaran Tematik Terpadu. Jakarta: PT Raja Grafindo Persada.

Sudjana, Nana. 2000. Dasar-Dasar Proses Belajar Mengajar. Bandung: PT Sinar Baru Algensindo.

Sugiono. 2015. Metode Penelitian Pendidikan. Bandung: Alfabeta.

Sundayana, Rostina. 2016. Media Alat Peraga Dalam Pembelajaran Matematika. Bandung: Alfabeta.

Uno, dan Kuadrad. 2010. Mengelola Kecerdasan Dalam Pembelajaran. Jakarta: Bumi Aksara.

Trianto. 2014. Mendesain Model Pembelajaran Inovatif, Progresif, dan Kontekstual. Jakarta: Prenadamedia Group.

Widoyoko. 2012. Teknik Penyusunan Instrumen Penelitian. Yogyakarta: Pustaka Belajar. 